\title{
Clinical characteristics of Creutzfeldt-Jakob disease in Mexico: A retrospective analysis
}

\author{
José A. Choreño-Parra ${ }^{1,2}$, Francisco J. Pacheco-Sánchez ${ }^{1,3,4}$, Alberto I. Rodríguez-Nava 1,3,4, \\ Gabriela García-Quintero ${ }^{1,3,4}$, Patricia E. Rodríguez-Muñoz ${ }^{1}$, and Parménides Guadarrama-Ortiz ${ }^{1 *}$
}

${ }^{1}$ Department of Neurosurgery, Centro Especializado en Neurocirugía y Neurociencias México (CENNM); ${ }^{2}$ Escuela Nacional de Ciencias Biológicas, Instituto Politécnico Nacional; 3 Internado Médico de Pregrado, CENNM; ${ }^{4}$ Escuela Nacional de Medicina y Homeopatía, Instituto Politécnico Nacional. Mexico City, Mexico

\begin{abstract}
Background: Little is known about the clinical characteristics and significance of Creutzfeldt-Jakob disease (CJD) in Mexico. Objective: This study aimed to conduct a retrospective revision and analysis of the clinical cases of Mexican patients with CJD available in the literature. Methods: We systematically searched electronic databases for studies in English and Spanish conducted in Mexico over the period of 1990-2020 that involved Mexican patients with any of the clinical forms of CJD. Clinical variables were extracted from the selected studies that met eligibility criteria. Descriptive statistics were used to characterize the study population. Results: $A$ total of seven studies were included in the analysis. From these, 29 cases were revised, and their clinical characteristics analyzed. The median age at the time of diagnosis was 54 years (range 23-75 years). CJD was more frequent among females than male patients (male:female ratio 1:1.41). Most patients resided in Mexico City and the State of Mexico, and 93\% attended public hospitals. The most frequent form of CJD was sporadic, with only two probable cases of familiar disease. The most common clinical symptoms observed in order or frequency were rapidly progressive dementia (68.9\%), cerebellar signs (51.7\%), neuropsychiatric symptoms (51.7\%), akinetic mutism $(51.7 \%)$, myoclonus $(44,8 \%)$, extrapyramidal signs ( $44.8 \%)$, visual disturbances $(41.3 \%)$, pyramidal signs $(31 \%)$, and sleep disorders (17.2\%). Only 20\% of the cases were confirmed by histopathological analysis of brain biopsy or autopsy specimens. Conclusions: Our study provides an overview of the main clinical characteristics of CJD in Mexican patients.
\end{abstract}

Key words: Creutzfeldt-Jakob disease. Prion. Cognitive decline. Rapidly progressive dementia. Spongiform encephalopathy.

\section{Características clínicas de la enfermedad de Creutzfledt-Jakob en México: un análisis retrospectivo}

\section{Resumen}

Antecedentes: Se sabe poco sobre las características clínicas y la importancia de la enfermedad de Creutzfeldt-Jakob (ECJ) en México. Objetivo: Este estudio tuvo como objetivo realizar una revisión y análisis retrospectivo de los casos clínicos de pacientes mexicanos con ECJ disponibles en la literatura. Métodos: Se hizo una búsqueda sistemática en bases de datos electrónicas de estudios en inglés y español realizados en México durante el período de 1990 a 2020, que involucraron

\section{Correspondence:}

*Parménides Guadarrama-Ortiz

Date of reception: 14-09-2020

E-mail: investigacion.cientifica@cennm.com,_ Date of acceptance: 14-10-2020

dr.guadarrama.ortiz@cennm.com

DOI: 10.24875/RMN.20000099

1665-5044/ (c) 2020 Academia Mexicana de Neurología A.C. Published by Permanyer. This is an open access article under the CC BY-NC-ND license (http://creativecommons.org/licenses/by-nc-nd/4.0/). 
a pacientes mexicanos con cualquiera de las formas clínicas de ECJ. Se extrajeron variables clínicas de los estudios seleccionados que cumplieron con los criterios de elegibilidad. Se utilizó estadística descriptiva para caracterizar la población de estudio. Resultados: Se incluyó un total de siete estudios en el análisis. De estos, se revisaron 29 casos y se analizaron sus características clínicas. La mediana de edad en el momento del diagnóstico fue de 54 años (rango de 23 a 75 años). La ECJ fue más frecuente entre las mujeres que entre los hombres (proporción hombre: mujer 1: 1.41). La mayoría de los pacientes residían en la Ciudad de México y el Estado de México y el 93\% acudía a hospitales públicos. La forma más frecuente de ECJ fue esporádica, con solo dos casos probables de enfermedad familiar. Los síntomas clínicos más comunes observados en orden o frecuencia fueron demencia rápidamente progresiva (68.9\%), signos cerebelosos $(51.7 \%)$, síntomas neuropsiquiátricos (51.7\%), mutismo acinético (51.7\%), mioclonías (44.8\%), signos extrapiramidales. (44.8\%), alteraciones visuales (41.3\%), signos piramidales (31\%) y trastornos del sueño (17.2\%). Solo el $20 \%$ de los casos fueron confirmados por análisis histopatológico de biopsias cerebrales o muestras de autopsias. Conclusiones: En conclusión, nuestro estudio ofrece una visión general de las principales características clínicas de la ECJ en pacientes mexicanos.

Palabras clave: Enfermedad de Cretuzfeldt-Jakob. Prion. Deterioro cognitivo. Demencia rápidamente progresiva. Encefalopatía espongiforme.

\section{Introduction}

Creutzfeldt-Jakob disease (CJD) is the most frequent variant among human spongiform encephalopathies (SE). This rare and invariably fatal neurological disorder is characterized clinically by rapidly progressive dementia, myoclonus, and periodic activity in the electroencephalogram (EEG). Such clinical features are associated with a global loss of cerebral tissue due to the spread of an alternative-folded "scrapie prion protein" $\left(\mathrm{PrPS}^{\mathrm{Sc}}\right)$ within the central nervous system (CNS) ${ }^{1,2}$. Notably, CJD is a unique condition that can occur as a sporadic (sCJD), familiar (fCDJ), contagious (vCJD), or iatrogenic (iCJD) disorder depending on the underlying causative mechanism. Nonetheless, the variety of SCJD accounts for about $85 \%$ of all CJD cases ${ }^{3,4}$.

The natural variant of the prion protein $(\operatorname{PrPC})$ has a longitude of 209 amino acids and is codified by the PRNP gene on chromosome 20. This protein, anchored to the surface of neurons, plays several essential roles in the homeostasis of neural cell functions ${ }^{5}$. $\mathrm{PrPC}^{\mathrm{C}}$ is characterized by a $\mathrm{C}$-terminal region containing a more significant proportion of $\alpha$-helices than $\beta$-sheet structures. This feature provides the protein the properties of being monomeric, soluble, and protease-sensitive. However, several alterations can lead to $\operatorname{PrP}^{\mathrm{C}}$ to acquire an alternative folding that consists of a gain of $\beta$-sheet structures and results in the conversion of $\mathrm{PrPC}$ into PrPSc6. In fCJD cases, a wide range of autosomal dominant inherited mutations in the PRNP gene makes $\operatorname{PrP}^{\mathrm{C}}$ more prone to acquire an alternative-folding. In contrast, in the iCJD and vCJD forms, the abnormal PrPSc is transmitted by consumption of contaminated food or iatrogenic exposure to infectious nervous tissue, respectively. Once in the brain, PrPsc induces its self-replication by template conversion of $\operatorname{PrP}^{\mathrm{C}}$. On the other hand, the specific cause of spontaneous conversion of $\mathrm{PrPC}$ into PrPSc in SCJD remains unknown, but a failure of the mechanisms controlling protein folding may be implicated ${ }^{3,7}$.

At present, the definitive confirmation of CJD is by histopathological analysis of brain biopsy or autopsy specimens. This analysis must show amyloid deposits of PrPsc, astrogliosis, spongiform degeneration, and vacuolization of the neuropil ${ }^{8}$. In Mexico, there are few reports of CJD, and the real incidence of this and other forms of SE remain unknown. This is due to the clinical heterogeneity of CJD and the lack of awareness of the disease among physicians. Furthermore, the absence of laboratories technically capable of conducting special cerebrospinal fluid (CSF) studies, and the diminished performance of autopsies has complicated the surveillance concerning CJD. Furthermore, the prevalence of the distinct forms of CJD and the clinical manifestations that more frequently affect Mexican patients with this disorder are unknown.

Here, we performed a comprehensive review of the literature looking for studies of the clinical characteristics of Mexican patients with CJD. Our study shows a high frequency of the classic cognitive deficits of CJD in Mexicans, as well as a high frequency of cerebellar manifestations. Furthermore, our analysis reveals a low incidence of this disease in our country that perhaps is underestimated due to several deficiencies in the diagnostic approach to CJD in health institutions of Mexico. This review may contribute to improving our understanding of the clinical features of CJD in Mexican patients, which ultimately can generate improvements in the diagnostic approach to this disorder. 


\section{Materials and methods}

\section{Search strategy}

We systematically searched for studies conducted in Mexico involving non-Caucasian Hispanic patients with any of the clinical forms of CJD. The following electronic databases were searched for both published and unpublished studies in the English and Spanish language over the period of 1990-2020: PubMed, EMBASE, Web of Science, Scientific Electronic Library Online (SciELO), and Google Scholar. The following terms were used to generate a search: Creutzfeldt-Jakob disease, prion, clinical characteristics, clinical features, Mexico, and Mexican. The selection criteria for papers included: (a) primary research; (b) full-text paper in English or Spanish; (c) a general population (e.g., not a single age group or gender); and (d) letters to editor, case reports, case series, cross-sectional, and longitudinal studies. Two reviewers independently performed the literature search and screened the abstracts and full text according to these eligibility criteria. The reference list of the included studies was checked to reduce literature omissions.

\section{Data retrieval}

The two reviewers who performed the literature search also independently extracted the data from the selected studies. Microsoft Excel (MS Excel 365) was used for data collection. We extracted the following variables: age, gender, state of residence in Mexico, comorbidities, family history of rapidly progressive dementia, the clinical variant of CJD (sCJD, fCJD, iCJD, and $V C J D$ ), neurological manifestations, the interval between symptoms onset to hospital admission, type of medical care received (public or private), diagnostic tests employed, and category of diagnosis according to the clinical probability of disease (possible, probable, or definitive). Categories of diagnosis were defined following the 2018 diagnostic criteria for CJD of the Centers for Disease Control and Prevention $(C D C)^{9}$, as shown in Table 1.

\section{Data analysis}

Descriptive statistics were used to characterize the study population clinically. Frequencies and proportions were calculated for categorical data. Means, medians, standard deviations (SD), and interquartile ranges (IQR) were used for continuous variables.

\section{Results}

Fifty articles were identified from the searched electronic databases. From these, seven studies met the inclusion criteria and were selected in this review (Table 2) ${ }^{10-16}$. A total of 29 cases of CJD were reported over the period of 1990-2020 in Mexico. The clinical and demographic data of these cases are summarized in Table 3. The median age reported was 54 years. The youngest and oldest Mexican patients with CJD had 23 and 75 years old, respectively. The disease was more frequent in females $(58.62 \%)$ than in male $(41.37 \%)$ patients, with a male to female ratio of 1:1.41. Mexico City and the State of Mexico were the mean regions of patients' residency, probably reflecting the centralization of the health-care services rather than the real distribution of CJD in Mexico. The relevant comorbidities most frequently observed among CJD patients were diabetes and hypertension, two medical conditions highly prevalent in the Mexican population.

The most common neurological findings of frequency were rapidly progressive dementia, cerebellar signs, neuropsychiatric symptoms, akinetic mutism, myoclonus, extrapyramidal signs, visual disturbances, pyramidal signs, and sleep disorders. Median of days between disease onsets, defined as the moment when the patients reported the first symptoms, to hospital admission was 64 . However, this interval varied from 9 days to 2 years. The most frequent clinical form of CJD was sporadic, with only two cases of probable fCJD. These cases were not confirmed by the demonstration of an inherited mutation in the PRNP gene, but they reported a family history of similar cases in first-degree relatives. There were no reports of iCJD and VCJD in the literature searched. The survival of Mexican patients with CJD could not be estimated since a fraction of the cases was not further followed until death.

According to the 2018 CDC's criteria for CJD (9), $44.82 \%$ of the cases reported in Mexico met the criteria for probable CJD. Meanwhile, $34.48 \%$ of patients reported can be categorized as possible CJD, and only six patients (20.68\%) were considered as definitive cases, as they were confirmed by histopathological analysis of autopsy brain specimens (Table 4). The majority of Mexican patients with CJD attended public health institutions (93.1\%), whereas only two cases received private medical care. EEG was the most frequent diagnostic tool employed for the diagnostic approach of CJD in Mexican patients, followed by brain magnetic resonance imaging (MRI), CSF levels of 14-3-3 protein, brain single-photon emission computed tomography 
Table 1. CDC's Diagnostic criteria for CJD, 2018

\begin{tabular}{|c|c|c|}
\hline Form of CJD & $\begin{array}{l}\text { Diagnostic } \\
\text { subtype }\end{array}$ & Criteria \\
\hline \multirow[t]{3}{*}{ Sporadic CJD } & Definite & $\begin{array}{l}\text { Diagnosed by standard neuropathological techniques; and/or immunocytochemically; and/or Western } \\
\text { blot confirmed protease-resistant PrP; and/or presence of scrapie-associated fibrils. }\end{array}$ \\
\hline & Probable & $\begin{array}{l}\text { Neuropsychiatric disorder plus positive RT-QuIC in cerebrospinal fluid (CSF) or other tissues } \\
\text { OR } \\
\text { Rapidly progressive dementia; and at least two out of the following four clinical features: } \\
\text { 1. Myoclonus } \\
\text { 2. Visual or cerebellar signs } \\
\text { 3. Pyramidal/extrapyramidal signs } \\
\text { 4. Akinetic mutism } \\
\text { AND a positive result on at least one of the following laboratory tests: } \\
\text { - A typical EEG (periodic sharp wave complexes) during an illness of any duration; and/or } \\
\text { - A positive 14-3-3 cerebrospinal fluid (CSF) assay in patients with a disease duration of less than } 2 \text { years } \\
\text { - Magnetic resonance imaging (MRI) high signal abnormalities in caudate nucleus and/or putamen } \\
\text { on diffusion-weighted imaging (DWI) or fluid attenuated inversion recovery (FLAIR) } \\
\text { AND without routine investigations indicating an alternative diagnosis. }\end{array}$ \\
\hline & Possible & $\begin{array}{l}\text { Progressive dementia; and at least two out of the following four clinical features: } \\
\text { 1. Myoclonus } \\
\text { 2. Visual or cerebellar signs } \\
\text { 3. Pyramidal/extrapyramidal signs } \\
\text { 4. Akinetic mutism } \\
\text { AND the absence of a positive result for any of the four tests above that would classify a case as "probable" } \\
\text { AND duration of illness < } 2 \text { years } \\
\text { AND without routine investigations indicating an alternative diagnosis. }\end{array}$ \\
\hline $\begin{array}{l}\text { latrogenic } \\
\text { CJD }\end{array}$ & -- & $\begin{array}{l}\text { Progressive cerebellar syndrome in a recipient of human cadaveric-derived pituitary } \\
\text { hormone; or sporadic CJD with a recognized exposure risk, for example, antecedent neurosurgery } \\
\text { with dura mater implantation. }\end{array}$ \\
\hline Familiar CJD & -- & $\begin{array}{l}\text { Definite or probable CJD plus definite or probable CJD in a first degree relative; and/or } \\
\text { neuropsychiatric disorder plus disease-specific } \operatorname{PrP} \text { gene mutation. }\end{array}$ \\
\hline
\end{tabular}

Table 2. Studies of CJD in Mexican patients

\begin{tabular}{|l|l|l|c|c|}
\hline Author & Year & $\begin{array}{l}\text { Type of } \\
\text { study }\end{array}$ & $\begin{array}{c}\text { Number } \\
\text { of cases }\end{array}$ & Reference \\
\hline $\begin{array}{l}\text { Martínez Barros, } \\
\text { et al. }\end{array}$ & 1995 & Case series & 3 & 10 \\
\hline $\begin{array}{l}\text { Calderón- } \\
\text { Garcidueñas, et al. }\end{array}$ & 2001 & Case report & 1 & 11 \\
\hline $\begin{array}{l}\text { Reyes, et al. } \\
\text { Velásquez-Pérez, } \\
\text { et al. }\end{array}$ & 2002 & Case report & 1 & 12 \\
\hline $\begin{array}{l}\text { González-Duarte, } \\
\text { et al. }\end{array}$ & 2011 & Case series & 15 & 13 \\
\hline $\begin{array}{l}\text { Restrepo-Martínez, } \\
\text { et al. }\end{array}$ & 2019 & $\begin{array}{l}\text { Letter to } \\
\text { editor }\end{array}$ & 7 & 14 \\
\hline $\begin{array}{l}\text { Guadarrama-Ortíz, } \\
\text { et al. }\end{array}$ & 2020 & Case report & 1 & 15 \\
\hline
\end{tabular}

(SPECT), and histopathological analysis. Only one case was tested for special CSF studies, such as levels of T-tau protein ${ }^{16}$. Furthermore, 18-fluorodeoxyglucose positron emission tomography $\left({ }^{18} \mathrm{FDG}-\mathrm{PET}\right)$ was performed in one patient ${ }^{15}$. Finally, only one case was confirmed by a real-time quaking-induced conversion (RT-QulC) test ${ }^{16}$, a novel technique with the highest diagnostic performance to detect minimal amounts of $\mathrm{PrPSc}^{\text {in CSF samples }}{ }^{17}$.

\section{Discussion}

The knowledge about the incidence, clinical characteristics, and epidemiological significance of CJD in Mexico is limited. Our study aimed to retrospectively revise and analyze available reports about the main manifestations of CJD in Mexican patients. A striking finding of our analysis was the low amount of cases from Mexico formally described in the literature. Indeed, only 29 patients with CJD have been reported over the past three decades in our country, which is $<1$ case/ year. This finding undoubtedly reflects a high grade of underreporting and sub-diagnosis of CJD cases in Mexicans. For instance, if we took the global incidence of SCJD as a reference (1 case per million people per 
Table 3. Demographic and clinical characteristics of CJD cases reported in Mexico

\begin{tabular}{|c|c|}
\hline Characteristic & $n=29(\%)$ \\
\hline Age (years), median (range) & $54(23-75)$ \\
\hline $\begin{array}{l}\text { Gender } \\
\text { Male } \\
\text { Female } \\
\text { Male: female ratio }\end{array}$ & $\begin{array}{c}12(41.37) \\
17(58.62) \\
1: 1.41\end{array}$ \\
\hline $\begin{array}{l}\text { Place of residence } \\
\text { Mexico City } \\
\text { State of Mexico } \\
\text { Other States* } \\
\text { Not reported }\end{array}$ & $\begin{array}{l}11(37.93) \\
6(20.68) \\
7(24.13) \\
4(13.79)\end{array}$ \\
\hline $\begin{array}{l}\text { Type of diagnosis } \\
\text { Definitive } \\
\text { Probable } \\
\text { Possible }\end{array}$ & $\begin{array}{l}6(20.68) \\
13(44.82) \\
10(34.48)\end{array}$ \\
\hline $\begin{array}{l}\text { Clinical CJD form } \\
\text { sCJD } \\
\text { fCJD** } \\
\text { iCJD } \\
\text { vCJD }\end{array}$ & $\begin{array}{c}26(89.65) \\
2(6.89) \\
0 \\
0\end{array}$ \\
\hline $\begin{array}{l}\text { Clinical features } \\
\text { Rapidly progressive dementia } \\
\text { Myoclonus } \\
\text { Akinetic mutism } \\
\text { Visual disturbances } \\
\text { Cerebellar signs } \\
\text { Pyramidal signs } \\
\text { Extrapyramidal signs } \\
\text { Sleep disorders } \\
\text { Neuropsychiatric symptoms } \\
\text { (depression, anxiety, behavioral changes) } \\
\text { Symptoms onset to hospital admission interval } \\
\text { (days), median (range) } \\
\text { Family history of rapidly progressive dementia }\end{array}$ & $\begin{array}{c}20(68.96) \\
13(44.82) \\
15(51.72) \\
12(41.37) \\
15(51.72) \\
9(31.03) \\
13(44.82) \\
5(17.24) \\
15(51.72) \\
64(9-730) \\
2(6.89)\end{array}$ \\
\hline $\begin{array}{l}\text { Relevant comorbidities } \\
\text { Diabetes } \\
\text { Hypertension } \\
\text { Cancer }\end{array}$ & $\begin{array}{c}3(10.34) \\
4(13.79) \\
1(3.44)\end{array}$ \\
\hline $\begin{array}{l}\text { Type of medical care } \\
\text { Public care } \\
\text { Private care }\end{array}$ & $\begin{array}{c}27(93.1) \\
2(6.89)\end{array}$ \\
\hline
\end{tabular}

*Hidalgo, Sonora, Veracruz, Michoacán, Morelos, Jalisco, Coahuila.

**Individuals with a family history of rapidly progressive dementia but no confirmation of inherited mutations in the PRNP gene (probable fCJD).

year) ${ }^{3}$, then the expected number of CJD cases occurring in Mexico would be much higher.

These data are in part due to the rarity and unspecific manifestations of CJD. In this sense, it is well recognized that rapidly progressive dementia is not a unique characteristic of this disease. In fact, many other neurological disorders can be confused with CJD, including some variants of Alzheimer disease (AD), dementia with Lewy bodies (DLB), frontotemporal dementia
Table 4. Diagnostic approach to CJD in Mexico

\begin{tabular}{|l|c|c|c|}
\hline & $\begin{array}{c}\text { Public } \\
\text { hospital care } \\
(\mathbf{n}=\mathbf{2 7})(\%)\end{array}$ & $\begin{array}{c}\text { Private } \\
\text { hospital care } \\
(\mathbf{n}=\mathbf{2})(\%)\end{array}$ & $\begin{array}{c}\text { Total } \\
(\mathbf{n}=\mathbf{2 9})(\%)\end{array}$ \\
\hline MRI & $20(74.07)$ & $2(100)$ & $22(75.86)$ \\
\hline EEG & $26(96.29)$ & $2(100)$ & $27(93.1)$ \\
\hline SPECT & $7(25.92)$ & 0 & $7(24.13)$ \\
\hline${ }^{18}$ FDG-PET & $1(3.7)$ & 0 & $1(3.44)$ \\
\hline CSF 14-3-3 protein & $14(51.85)$ & $2(100)$ & $16(55.17)$ \\
\hline CSF Tau protein & 0 & $1(50)$ & $1(3.44)$ \\
\hline CSF RT-QulC & 0 & $1(50)$ & $1(3.44)$ \\
\hline $\begin{array}{l}\text { Histopathological } \\
\text { analysis }\end{array}$ & $6(22.22)$ & 0 & $6(20.68)$ \\
\hline
\end{tabular}

CSF: cerebrospinal fluid, EEG: electroencephalogram, MRI: magnetic resonance imaging, RT-QuIC: real time quaking-induced conversion test, SPECT: single photon emission computed tomography, 18-fluorodeoxyglucose positron emission tomography.

(FTD), viral, bacterial, parasitic, or autoimmune meningoencephalitis (e.g., Hashimoto's encephalitis, and limbic encephalitis), corticobasal degeneration, progressive supranuclear palsy, paraneoplastic encephalomyelitis, and even vascular dementia ${ }^{18,19}$. Furthermore, a wide range of other clinical manifestations, such as pyramidal/extrapyramidal dysfunction, ataxia, cerebellar signs, psychiatric symptoms, visual disturbances, sleep disorders, akinetic mutism, and persistent painful sensory symptoms, may be present among patients with $\mathrm{CJD}^{1}$, adding complexity to the clinical spectrum of the disease. This fact led physicians to subclassify various forms of CJD according to the mean symptoms, including the classic (dyskinetic), Heidenhain (visual), myoclonic, cerebellar (ataxic), thalamic, amyotrophic, and panencephalopathic forms $\mathrm{s}^{4,7}$.

Furthermore, it is, currently, well known that, in the specific case of SCJD, the clinical heterogeneity is also associated with some genetic and molecular features of the pathogenic PrPsc. Specifically, methionine (M) or valine (V) polymorphism at codon 129 of the PRNP gene ${ }^{20}$, as well as the type of electrophoretic mobility pattern of PrPSc after protease digestion (type 1 and 2), are used to classify patients into several phenotypes separated into three categories: SCJD cognitive subtypes (MM1, MV1, MM2, and VV1), ataxic subtypes (VV2 and MV2), and other non-sCJD subtypes (types 3 and 4 electrophoretic mobility for sporadic fatal insomnia ( $\mathrm{sFl}$ ) and variably protease-sensitive prionopathy (VPSPr), respectively $)^{4,7}$. Each category has unique 
characteristics differing from the others in age at onset, duration of the disease, dominant neurological findings, and among others. However, the age at onset of all CJD cases ranges from 50 to 70 years with no predilection for any gender.

The polymorphisms in the PRNP gene that determine the susceptibility for the development of SCJD are differentially distributed among various populations around the world ${ }^{21-24}$. However, the frequency of M129V genotypes and alleles in the Mexican population has not been addressed. Our results confirm that SCJD is the most frequent variant of this disease in Mexicans. Furthermore, there are only two cases of probable fCJD not confirmed by the demonstration of an inherited mutation in the PRNP gene. There is no registry of any case of acquired CJD through iatrogenic exposure or contagion, but there are cases in very young patients, and the wide range of interval between disease onset to hospital admission opens the possibility of the occurrence of vCJD/iCJD among Mexican individuals. We also observed that rapidly progressive dementia, akinetic mutism, and myoclonus were among the most common symptoms observed in Mexican CJD patients. Furthermore, neuropsychiatric symptoms were frequently reported, although only one case was formally categorized as a Heidenhain variant of CJD ${ }^{15}$. These data indicate that the SCJD cognitive subtypes are common in Mexicans with this disease. Thus, we can predict that the underlying genetic and molecular traits of these phenotypes (MM1, MV1, MM2, and VV1) would be frequent in our population.

Interestingly, we found a high number of patients with CJD that presented cerebellar symptoms $(51.72 \%)$, including ataxia. The frequency of cerebellar affection in CJD patients from other regions has not been comprehensively estimated. In a study conducted in the United Kingdom, cerebellar ataxia occurred as the only clinical manifestation in $5 \%$ of patients with CJD ${ }^{25}$. In contrast, in a study of Chinese patients with CJD, up to $51.9 \%$ of affected individuals presented cerebellar ataxia ${ }^{26}$, which coincides with our findings. Thus, based on our results, we also predict that the genetic and molecular characteristics of the PrPSc underlying ataxic subtypes of SCJD (VV2 and MV2) may have a high incidence in Mexico.

The variable clinical characteristics of CJD complicate the diagnostic approach and opportune detection of positive cases. Furthermore, the low level of clinical suspicion among physicians and the absence of a formal surveillance strategy may further contribute to the underestimation of the burden of CJD in the Mexican population. To improve the diagnosis and global surveillance of CJD, the CDCs have established several diagnostic criteria that classify each case according to the likelihood of the disease based on clinical features and the results of different laboratory and imaging tests ${ }^{9}$. Possible and probable categories are based on clinical symptoms and positive results in EEG, MRI, and CSF 14-3-3. Most such studies have high specificity but low sensitivity, and it is important to mention that their diagnostic reliability varies according to the CJD form and even to the SCJD subtype ${ }^{27}$.

EEG recording in patients with SCJD typically shows pseudo-periodic sharp-wave complexes (PSWC) with diffuse slowly background activity at the middle and late stages of the disease. The diagnostic value of EEG is due to its $64 \%$ sensitivity and $91 \%$ specificity ${ }^{28}$. On the other hand, MRI has shown to have better diagnostic performance due to improvements in the DWI sequence $^{29}$. MRI does not allow to distinguish between clinical forms of CJD, but in cases of VCJD, a posterior thalamus involvement (pulvinar sign) supports the diagnosis $^{30}$. CSF levels of neuron-specific enolase (NSE) and T-tau protein have also been proposed as biomarkers of CJD. From these, T-tau protein has the highest sensitivity and specificity with a cutoff of $1150 \mathrm{pg} / \mathrm{mL}^{31}$. However, CSF levels of T-tau protein have not been integrated into the 2018 CDC's diagnostic criteria for CJD.

Notably, in the last decade, RT-QuIC has emerged as a novel alternative for premortem diagnosis of CJD with better performance compared with other CSF tests. This assay relies on the in vitro template conversion of recombinant $\mathrm{PrPC}^{\mathrm{C}}$ into $\mathrm{PrPS}^{\mathrm{Sc}}$, evidenced through a fluorescent indicator, allowing to detect minute amounts of PrPsc in biological samples with high sensitivity and specificity ${ }^{17}$. Indeed, we recently reported the first case of a Mexican patient with SCJD confirmed by a complete battery of diagnostic tests, including EEG, MRI-DWI, CSF levels of T-tau, and 14-3-3 protein, as well as CSF RT-QuIC, which allowed us to detect this case premortem (16). In such a report, we demonstrated an excellent correlation between the results of the RT-QulC test and other clinical and laboratory parameters. Despite this, RT-QuIC is not considered as a diagnostic tool that can classify a patient as a definitive case of CJD by the CDCs. Thus, the definitive diagnosis of CJD is still based on the histopathological analysis of brain biopsy and autopsy specimens.

Our study reveals concerning data about the diagnostic approach to CJD in our country. First, we observed that only $20 \%$ of cases were confirmed by 
histopathology. The definitive confirmation of CJD in Mexicans was exclusively performed in public healthcare institutions. More specific and sophisticated imaging and CSF tests were rarely performed in public hospital care, and they were carried out in laboratories outside Mexico, even in cases diagnosed at private hospitals. These facts must claim the attention of national health-care authorities to make the efforts needed to create laboratories with the technical capacity to perform special CSF studies and to introduce new tests that allow confirming CJD in Mexico, such as the RTQulC test.

\section{Conclusions}

Our study provides an overview of the main clinical characteristics of CJD in Mexican patients. Also, our study reveals that the incidence of CJD in our country could be higher than supposed. Finally, we remarked several deficiencies in the diagnostic approach to this neurological disorder in our country that needs the attention of the Mexican authorities of health. Our findings should motivate Mexican physicians and researchers to get involved in the surveillance and improvement of diagnosis of the disease

\section{Funding}

The current study did not receive financial support.

\section{Conflicts of interest}

The authors declare that they have not conflicts of interest.

\section{Acknowledgments}

The authors would like to thank the medical and nursing staff of our center, for their critical reading and comments on our manuscript.

\section{Ethical disclosures}

Protection of human and animal subjects. The authors declare that no experiments were performed on humans or animals for this study.

Confidentiality of data. The authors declare that no patient data appear in this article.

Right to privacy and informed consent. The authors declare that no patient data appear in this article.

\section{References}

1. Prusiner SB. The prion diseases. Brain Pathol. 1998:8:499-513.

2. Prusiner SB. Novel proteinaceous infectious particles cause scrapie. Science. 1982;216:136-44.

3. Chen C, Dong XP. Epidemiological characteristics of human prion diseases. Infect Dis Poverty. 2016;5:47.

4. Imran M, Mahmood S. An overview of human prion diseases. Virol J. 2011;8:559.

5. Castle AR, Gill AC. Physiological functions of the cellular prion protein Front Mol Biosci. 2017;4:19.

6. Prusiner SB. Prions. Proc Natl Acad Sci U S A. 1998;95:13363-83.

7. Kovacs GG, Budka H. Molecular pathology of human prion diseases. Int J Mol Sci. 2009;10:976-99.

8. Budka H. Neuropathology of prion diseases. Br Med Bull. 2003;66:121-30.

9. Centers for Disease Control and Prevention. CDC's Diagnostic Criteria for Creutzfeldt-Jakob Disease (CJD); 2018. Available from: https://www. cdc.gov/prions/cjd/diagnostic-criteria.html.

10. Barros MM, Peek JR, Vega R, Escobar A. Creutzfeldt-Jakob disease. Clinical, electrophysiological and histopathological correlations. Gac Med Mex. 1995;131:591-6.

11. Calderón-Garcidueñas AL, Sagastegui-Rodríguez JA, Canales-lbarra C, Farías-García R. A case of Creutzfeldt-Jakob in the Mexican North-East and review of current concepts on prion disease. Gac Med Mex. 2001;137:589-94.

12. Reyes MT, Aguilar S, Corona R, Vega I, Colón CM, Ramos GG. Enfermedad de Creutzfeldt-Jakob: reporte de un caso y revisión de la literatura. Med Sur. 2002:9:79-87.

13. Velásquez-Pérez L, Rembao-Bojorquez D, Guevara J, Guadarrama-Torres RM, Trejo-Contreras A. Creutzfeldt-Jakob disease in Mexico. Neuropathology. 2007;27:419-28.

14. González-Duarte A, Medina Z, Balaguer RR, Calleja JH. Can prion disease suspicion be supported earlier? Clinical, radiological and laboratory findings in a series of cases. Prion. 2011;5:201-7.

15. Restrepo-Martínez M, Chacón-González J, Oñate-Cadena N, Bayliss L. Neuropsychiatric symptoms in the Heidenhain variant of Creutzfeldt-Jakob's disease mistaken for major depression and functional neurological disorder. Aust N Z J Psychiatry. 2019;53:1222-3.

16. Guadarrama-Ortíz P, Choreño-Parra JA, Carnalla-Cortés M, Rodríguez-Muñoz PE, Ángeles-Castellanos M. A complete and state of the art pre-mortem diagnostic approach to Creutzfeldt-Jakob disease: a case report. Neurol India. 2020;68:1-3.

17. Orrú CD, Groveman BR, Hughson AG, Zanusso G, Coulthart MB, Caughey B. Rapid and sensitive RT-QulC detection of human Creutzfeldt-Jakob disease using cerebrospinal fluid. mBio. 2015;6:e02451-14.

18. Paterson RW, Torres-Chae CC, Kuo AL, Ando T, Nguyen EA, Wong K, et al. Differential diagnosis of Jakob-Creutzfeldt disease. Arch Neurol. 2012;69:1578-82.

19. Mead S, Rudge P. CJD mimics and chameleons. Pract Neurol. 2017;17:113-21

20. Saba R, Booth SA. The genetics of susceptibility to variant Creutzfeldt-Jakob disease. Public Health Genomics. 2013;16:17-24.

21. Lee SM, Ju YR, Choi BY, Hyeon JW, Park JS, Kim CK, et al. Genotype patterns and characteristics of PRNP in the Korean population. Prion. 2012;6:375-82.

22. Saetta AA, Michalopoulos NV, Malamis G, Papanastasiou PI, Mazmanian N, Karlou M, et al. Analysis of PRNP gene codon 129 polymorphism in the Greek population. Eur J Epidemiol. 2006;21:211-5.

23. Yu SL, Jin L, Sy MS, Mei FH, Kang SL, Sun GH, et al. Polymorphisms of the PRNP gene in Chinese populations and the identification of a novel insertion mutation. Eur J Hum Genet. 2004;12:867-70.

24. Erginel-Unaltuna N, Peoc'h K, Komurcu E, Acuner TT, Issever H, Laplanche JL. Distribution of the M129V polymorphism of the prion protein gene in a Turkish population suggests a high risk for Creutzfeldt-Jakob disease. Eur J Hum Genet. 2001;9:965-8.

25. Cooper SA, Murray KL, Heath CA, Will RG, Knight RS. Sporadic Creutzfeldt-Jakob disease with cerebellar ataxia at onset in the UK. J Neurol Neurosurg Psychiatry. 2006;77:1273-5.

26. Qi C, Zhang JT, Zhao W, Xing XW, Yu SY. Sporadic Creutzfeldt-Jakob disease: a retrospective analysis of 104 cases. Eur Neurol. 2020;83:65-72.

27. Forner SA, Takada LT, Bettcher BM, Lobach IV, Tartaglia MC, Torres-Chae C, et al. Comparing CSF biomarkers and brain MRI in the diagnosis of sporadic Creutzfeldt-Jakob disease. Neurol Clin Pract. 2015;5:116-25.

28. Wieser HG, Schindler K, Zumsteg D. EEG in Creutzfeldt-Jakob disease. Clin Neurophysiol. 2006;117:935-51.

29. Fujita K, Harada M, Sasaki M, Yuasa T, Sakai K, Hamaguchi T, et al. Multicentre multiobserver study of diffusion-weighted and fluid-attenuated inversion recovery MRI for the diagnosis of sporadic Creutzfeldt-Jakob disease: a reliability and agreement study. BMJ Open. 2012;2:e000649-e.

30. Zeidler M, Sellar RJ, Collie DA, Knight R, Stewart G, Macleod MA, et al. The pulvinar sign on magnetic resonance imaging in variant Creutzfeldt-Jakob disease. Lancet. 2000;355:1412-8.

31. Hamlin C, Puoti G, Berri S, Sting E, Harris C, Cohen M, et al. A comparison of tau and 14-3-3 protein in the diagnosis of Creutzfeldt-Jakob disease. Neurology. 2012;79:547-52. 